\title{
Território e Participação: Lévy-Bruhl no país dos Karajá
}

\author{
Eduardo S. Nunes ${ }^{1}$
}

${ }^{1}$ Universidade Federal do Oeste do Pará, Santarém, PA, Brasil 


\section{Resumo}

O objetivo deste artigo é tentar extrair da obra de Lucien Lévy-Bruhl um conceito de "território" produtivo do ponto de vista do atual estado da literatura etnológica; extraí-lo e, em um segundo movimento, experimentálo a partir do material etnográfico Karajá. Depois de explorar brevemente alguns dos aspectos centrais da obra, do autor francês, sobretudo sua noção de participação, passa-se a elaborar o conceito karajá de hãwa, geralmente traduzido pelos índios por "território", como um "amontoado de participações e exclusões", segundo o entendimento de Lévy-Bruhl. Pois um hãwa associado a uma aldeia engloba vários territórios heterogêneos habitados por seres Outros, entre os quais, o que há não é uma divisão extensiva, mas uma superposição intensiva. Habitar um hãwa, portanto, demanda uma vívida percepção dos modos de relação que esse "amontoado" implica, bem como uma avaliação cuidadosa do que se pode ou não fazer, levando em conta as consequências, ou os efeitos, dessas ações - uma cosmopolítica do respeito.

Palavras-chave: Território. Participação. Lévy-Bruhl. Inỹ-Karajá.

\section{Abstract}

The present article aims to extract from Lucien Lévy-Bruhl's work a concept of "territory" that may be productive from the standpoint of the ethnological literature's current state; to extract it and, in a second movement, to experiment with it in reading the Karajá's ethnographic data. After a brief treatment of some of the central aspects of the French author's work, I explore the Karaja's concept of hãwa - usually translated by the Indians as "territory" - as a "huddle of participations and exclusions", according to Lévy-Bruhl's phrasing. For a hãwa associated to a village contains within it several heterogeneous territories inhabited by Other, different beings; and between which there is no extensive division, but intensive superposition. To live in a hãwa thus requires a vivid perception of the relational modes this "huddle" implies as well as a careful evaluation of that which one can or cannot do taking into account the consequences or effects of one's actions - a cosmopolitics of respect.

Keywords: Territory. Participation. LévyBruhl. Inỹ-Karajá. 


\section{Introdução}

Dor caminhos mais ou menos misteriosos, foi em negativo que a obra 1 de Lucien Lévy-Bruhl se tornou amplamente conhecida: o teórico da "mentalidade primitiva" tornou-se exemplo de o quão preconceituoso e autocentrado o olhar do velho mundo sobre as populações indígenas poderia ser. Caminhos mais ou menos misteriosos, eu diria, pois, por um lado, basta começar a ler qualquer um dos livros de sua fase etnológica para se dar conta que seu projeto intelectual se funda em um esforço radicalmente relativista, em uma luta incessante e violenta contra seus próprios "hábitos mentais" para lograr descrever em seus próprios termos o que ele chama, "na falta de um termo melhor" - expressão repetida à exaustão ao longo de seus textos -, de "mentalidade primitiva". Quando se o lê, escalar Lévy-Bruhl no rol de autores evolucionistas, por exemplo, se torna tarefa bastante trabalhosa, se não simplesmente um contrassenso. Quando se o lê, e esse é o aspecto menos misterioso da questão. Pois, como apontou Marcio Goldman (1999, p. 224), tal percepção da obra de Lévy-Bruhl não vem de sua leitura direta, mas daquelas de segunda, terceira ou quarta mãos. Tido antes como um contraexemplo, um exemplo do que não se fazer em antropologia, não era um autor a ser lido.

Um olhar atento para a obra etnológica de Lévy-Bruhl, porém, nos mostra que, ainda que inevitavelmente datada, ela conserva toda sua atualidade. Especialmente, penso eu, no que diz respeito a noção de participação, que tem um lugar central neste texto. Se não somente pela inspiração, pela experimentação que com ela faço, trazendo-a de outras paragens para o Brasil Central. Dedicando-me a um tema lateral (para dizer o mínimo) na obra do autor francês, o que proponho aqui é 
uma primeira tentativa de explorar o conceito de território presente em seus escritos, especialmente n'A mentalidade primitiva (2008 [1922]) explorar ou, antes, daí extraí-lo. Trazendo Lévy-Bruhl ao país dos Karajá, esse artigo experimenta com uma leitura do território (hãwa) desse grupo indígena como um "amontoado de participações e exclusões". Pois o hãwa de uma aldeia, veremos, engloba diversos outros territórios - de animais, espíritos, outros grupos indígenas, dos não-indígenas -, heterogêneos entre si. Engloba-os, no entanto, sem colapsar as diferenças entre (os territórios d)os diversos seres neles implicados. Um hãwa, sendo um, é muitos. As diferenças entre os múltiplos seres que o habitam o crivam internamente e o constituem: possuindo uma densidade ontológica própria, ele difere de si mesmo. Antes que uma segmentação extensiva da terra entre seres distintos, cada um tendo "posse" ou "domínio" sobre seu quinhão, o que encontramos são superposições intensivas.

Um conceito de "território" na obra de Lévy-Bruhl é, como dizia, lateral. Para ser mais preciso, a relação das coisas e seres (espíritos, humanos, animais...) com um determinado território aparecem, na pena do autor francês - como é o caso de praticamente todas as questões e elementos evidenciados nos fragmentos etnográficos por ele utilizados -, como um material bruto ("les faits") a partir do qual abstrai as características particulares da "mentalidade primitiva". Um tal conceito, portanto, aparece menos como uma elaboração direta (e, muito menos, exaustiva) do autor, que como um efeito ou consequência de seu entendimento da participação como fato fundamental, ou $a$ priori da mentalidade primitiva. Assim, menos que o argumento de um livro, ou o tema desenvolvido em um de seus capítulos, são alguns breves trechos d'A mentalidade primitiva que tomo como ponto de partida para essa reflexão. Seria possível, a partir deles, elaborar um conceito de território produtivo do ponto de vista do atual estado da literatura etnológica? Essa é a aposta do texto. Ou, antes, apostando que sim, o que o texto visa é experimentá-lo em um duplo movimento: primeiro dentro da obra de Lévy-Bruhl, depois a partir do material etnográfico karajá. Mas comecemos pelo princípio. Pois para extrair consequências significativas dessa experimentação, é preciso nos debruçarmos sobre 
aquilo que, para nosso autor francês, não é, justamente, lateral: os aspectos centrais de sua aproximação para com a mentalidade primitiva.

\section{Território em Lévy-Bruhl}

A imersão de Lévy-Bruhl na mentalidade primitiva começa, por meio da leitura de relatos etnográficos de diversas origens (da etnografia australiana precursora de Spencer e Gillen a relatos de missionários na África e alhures), com sua percepção de uma diferença inescapável para com mentalidade europeia, racional e fundada (ao menos em relação ao que lhe interessa) no princípio da não-contradição. Diferença essa evidenciada para ele sobretudo no que chama de "o insólito", acontecimentos para os quais as explicações indígenas se apresentavam, aos olhos dos observadores europeus, como absolutamente contrárias à ordem ou à causalidade natural dos fatos e, justamente por isso, contraditórias, para dizer o mínimo. Uma grande seca é atribuída pelos indígenas do Congo à vestimenta longa dos missionários católicos (Lévy-Bruhl, 1910, p. 71). Ainda na mesma região, onde abundam os crocodilos mas, a despeito disso, os ataques a humanos são raros, um incidente desse tipo é inevitavelmente atribuído à ação de um feiticeiro que 'se transforma' em crocodilo, ou 'entra no corpo' de um desses animais e o guia até a vítima (Lévy-Bruhl, 2008[1922], p. 41-2). Na América do Sul, K. von den Stein relata que os Trumai afirmam serem animais aquáticos, ao passo que os Bororo dizem 'friamente' que são araras (Lévy-Bruhl, 1910, p. 77). Mas como poderia a vestimenta dos padres causar uma seca? Como poderia uma pessoa se transformar em um animal, ou, mais ainda, ser um animal?

Em lugar de buscar uma razão deficiente ou negativa para acontecimentos como esses, Lévy-Bruhl procura uma razão "real e positiva" (2008[1922], p. 49). Em uma palavra, em lugar de tentar explicar a mentalidade primitiva por suas supostas carências, ele procura dar conta dela em seus próprios termos. Se os Bororo dizem que são araras, eles o são. O significado que isso assume para eles, porém, evidentemente não pode ser o mesmo que para o observador europeu. E a razão para isso é, e só poderia ser, que a mentalidade primitiva é uma mentalidade Outra. "Se existem sociedades humanas 
verdadeiramente diferentes umas das outras por suas instituições [...]", indaga Lévy-Bruhl (apud Cardoso de Oliveira, 1991, p. 146-147), “[...] esta diferença não deveria aparecer também na estrutura de seu espírito, ou como se diz, em sua mentalidade?" Quais, então, seriam as características da mentalidade primitiva?

Antes que guiada pelas leis da lógica ${ }^{1}$, ela seria pré-lógica. Esse termo, esclarece Lévy-Bruhl ainda em 1910,

[...] não deve nos levar a entender que esta mentalidade constitua uma forma anterior, no tempo, ao aparecimento do pensamento lógico. Teria existido grupos humanos ou pré-humanos cujas representações coletivas não obedeciam às leis lógicas? Ignoramos: contudo, é muito pouco provável. Pelo menos, a mentalidade que chamo de pré-lógica, na falta de termo melhor, não apresenta esse caráter. Ela não é antilógica; como também não é alógica. Chamando-a pré-lógica, pretendo dizer que ela não se limita acima de tudo, como em nosso pensamento, a abster-se da contradição. (Lévy-Bruhl, 1910, p. 79)²

Ela é pré-lógica porque opera, desde o início, por meio de uma síntese entre os acontecimentos concretos, de um lado, e seres e forças "místicas", de outro, entre natural e sobrenatural, estabelecendo, "[...] sem hesitação possível, a passagem imediata de tal percepção sensível para tal força invisível" (Lévy-Bruhl, 2008[1922], p. 50). A mentalidade primitiva, em suma, é essencialmente mística. As duas ideias - misticismo e pré-logismo - são, com efeito, dois aspectos de uma mesma questão. A princípio, Lévy-Bruhl distingue misticismo como dizendo respeito às "representação coletivas" dessa mentalidade, ao passo que o prélogismo se referiria às ligações entre essas representações. A esses dois conceitos, junta-se um terceiro, a participação, sobre a qual nos deteremos adiante.

Ao longo de sua obra, essa trinca vai sofrer algumas modificações. O misticismo é substituído pela "categoria afetiva do sobrenatural" para, por fim, ser caracterizado não como uma propriedade da mentalidade primitiva, mas como uma orientação. Quanto ao termo pré-lógico, os inúmeros mal-entendidos e dificuldades que gerou - a despeito da definição cuidadosa de Lévy-Bruhl (1952[1934], p. 120) acima citada -, levou o autor a reconhecer que a escolha do termo foi 
"infeliz" e, posteriormente, a abandoná-lo definitivamente (LévyBruhl, 2002[1949], p. 42-43). E a participação, que, no início, ainda sob influência clara do espírito positivista, é tratada como uma lei, passa a ser entendida como um fato (Lévy-Bruhl, 2002[1949], p. 52-53). Em seus Carnets, assim, restam de seu triângulo conceitual inicial apenas duas ideias fundamentais, a orientação mística e o fato da participação.

Uma análise detalhada do desenvolvimento desses conceitos ao longo da obra de Lévy-Bruhl seria um desvio extenso demais para o que esse texto se propõe. Um trabalho, além do mais, feito com maestria por Roberto Cardoso de Oliveira (1991) e, sobretudo, por Marcio Goldman (1994). O que gostaria de abordar aqui mais detidamente é a participação. O conceito aparece já em Les fonctios mentales dans les sociétés inférieurs como uma tentativa de caracterizar as relações entre as representações coletivas da mentalidade primitiva que não podiam ser explicadas "pelo desenvolvimento do pensamento obcecado pelas leis da lógica" (Lévy-Bruhl, 2002[1949], p. 52). "Na falta de uma fórmula satisfatória", de um "enunciado abstrato dessa lei", Lévy-Bruhl (1910, p. 77) apresenta, no entanto, uma "aproximação".

Eu diria que, nas representações coletivas de mentalidade primitiva, objetos, seres, fenômenos podem ser, de um modo incompreensível para nós, a um só tempo eles próprios e outra coisa eles próprios. De uma maneira não menos incompreensível, eles emitem e recebem forças, virtudes, qualidades, ações místicas, que se fazem sentir fora deles, sem deixar de ser o que eles são. Em outras palavras, para essa mentalidade, a oposição entre um e o múltiplo, entre o mesmo e o outro etc., não impõe a necessidade de afirmar um dos termos se ele nega o outro, ou vice-versa. Ela não tem mais que um interesse subsidiário. Às vezes, ela é percebida; muitas vezes, não o é. Ela muitas vezes se apaga face a uma comunidade mística de substância entre seres que, no entanto, para o nosso pensamento, não seriam confundidos sem disparate.

Se os Bororo dizem que são araras, isso não indica um devir póstumo ou uma metamorfose, "não é um nome que eles se dão, nem um parentesco que proclamam" (Lévy-Bruhl, 1910, p. 77). O que tem lugar entre os Bororo e as araras é uma participação. 
Que eles sejam a um só tempo os seres humanos que eles são e os pássaros de plumagem vermelha, $\mathrm{M}$. von den Stein julga inconvincente. Mas para uma mentalidade regida pela lei da participação, não há nenhuma dificuldade. (Lévy-Bruhl, 1910, p. 78)

A participação não é uma representação, nem uma analogia, nem uma metáfora; ela é uma conexão real, metonímica.

Uma participação, sobretudo, não é uma associação, Lévy-Bruhl insiste, pois não há termos preexistentes à participação que são por ela relacionados. O indivíduo, seu grupo e sua espécie totêmica, na Austrália, não são três realidades distintas, ainda que estreitamente relacionadas: para a mentalidade pré-lógica, “les 3 n'en font qu'une, tout en étant 3" (Lévy-Bruhl, 1910, p. 96), o que há é uma “[...] comunhão de essência onde se confundem o indivíduo atual, o ser ancestral que nele revive e a espécie animal ou vegetal que é seu totem" (Lévy-Bruhl, 1910, p. 95). A participação, em suma, é um a priori, expressando o caráter sintético da mentalidade primitiva.

Ela não representa seres cuja existência é concebida sem fazer recurso a outros elementos que aqueles desses próprios seres. Eles são o que são em virtude de participações: um membro de um grupo humano, por participação ao grupo e aos ancestrais; um animal ou uma planta por participação ao arquétipo da espécie etc. Se esta participação não fosse dada, já real, os indivíduos não existiriam. A questão não é: dados os objetos, os indivíduos, como eles podem participar uns dos outros? [...] Mas como indivíduos claramente definidos [...] emergem dessas participações? (Lévy-Bruhl, 2002[1946], p. 20)

A participação, poderíamos dizer, é a mola mestra do fundo de relacionalidade da mentalidade primitiva. E se, como a passagem acima diz, os seres "são o que são em virtude de participações" - ou, dizendo de outro modo, se as relações precedem os termos -, é a própria noção de "ser" que está em questão. Para a mentalidade primitiva, "ser é participar" (Lévy-Bruhl, 2002[1946], p. 20.). Não há, para ela, “um conceito rigoroso de individualidade una" (Lévy-Bruhl, 2002[1927], p. 130), de modo que, poderíamos dizer (e ainda que Lévy-Bruhl formule a participação, em mais de um lugar, como uma "comunhão 
de essência"), o ser não se constitui por uma semelhança em relação a si mesmo, i.e., uma identidade, mas por uma diferença interna.

O indivíduo não é ele mesmo que sob a condição de ser, ao mesmo tempo, outra coisa que ele mesmo. [...] Longe de ser um, como o concebemos, ele é a um só tempo um e vários. Ele é, portanto, por assim dizer, um verdadeiro lugar de participações. (Lévy-Bruhl, 2002[1927], p. 130)

Sendo um a priori, ou, como coloquei, uma propriedade do pano de fundo relacional da mentalidade primitiva, a participação não se faz presente apenas em um número limitado de casos; ela está, por assim dizer, em todo lugar, "[...] tudo implica uma participação entre os seres ou objetos ligados em uma representação coletiva" (Lévy-Bruhl, 1910, p. 76). Isso é evidenciado na diversidade de exemplos utilizados por Lévy-Bruhl. Diversidade essa que - e talvez não pudesse ser de outro modo - se refrata, em algum grau, sobre o próprio conceito de participação. No francês, nota Marcio Goldman, o verbo participer exige uma de duas preposições, à (participer à, "tomar parte de") ou de (participer de, "compartilhar de uma certa natureza"). “Ora, o fato é que Lévy-Bruhl utiliza quase indistintamente as duas preposições além de 'avec' e 'entre', quando se trata do substantivo 'participation' - o que sugere que o sentido do termo se difrata por esses dois campos semânticos: o primitivo 'faria parte de' outros seres e coisas, no duplo sentido de interagir misticamente com eles e de compartilhar de certa substância, também mística, com eles" (Goldman, 1994, p. 215). Oscilação que se dá a ver, note-se, já em sua "aproximação" ao conceito em 1910 (ver supra).

Também do ponto de vista etnográfico, a participação, como o próprio Lévy-Bruhl (1910, p. 78) reconhece, se apresenta "[...] de formas muito variadas: contato, transferência, simpatia, ação à distância etc.". Em seus Carnets, ele insiste sobre o ponto em mais de uma nota, falando dos “[...] diversos tipos de participação que, até o momento, eu não pude distinguir suficientemente" (Lévy-Bruhl, 2002[1949], p. 16). As "partes" (appartenances) destacadas do corpo de uma pessoa - "o cabelo, a saliva, o suor etc." (Lévy-Bruhl, 2002[1949], p. 16) - participam dela e, por isso, tomando uma passagem oportuna de outra obra, "[...] 
pode-se obter dela o que se obtém dele, pode-se agir sobre ele ao se agir sobre ela [...]" (Lévy-Bruhl, 1910, p. 79); entre a criança e seus pais há participação, de modo que "o neonato sofre o contragolpe de tudo o que seu pai faz, o que ele come etc." (Lévy-Bruhl, 1910, p. 78); o indivíduo participa de seu "grupo social" (Lévy-Bruhl, 2002 [1949], p. 64-66); o feiticeiro participa do crocodilo que é o veículo de seu malefício (Lévy-Bruhl, 2008[1922], p. 40-46); certos homens participam de certos animais nos quais se transformam "a cada vez que lhes vestem a pele (tigre, lobo, urso etc.)” (Lévy-Bruhl, 1910, p. 105); entre uma pessoa e seu duplo animal há, igualmente, participação, de modo que “[...] se o leopardo é ferido, o homem o é no mesmo momento e no mesmo local do corpo; se ele é morto, o homem também morrerá" (Lévy-Bruhl, 2002 [1949], p. 90); um lado de um pote com água utilizado para fins divinatórios antes de uma investida bélica não "representa" o inimigo, mas dele participa, de modo que "são os próprios guerreiros que estão na presença do inimigo", assim como o resultado da ação divinatória "é sua vitória ou derrota, das quais eles são atualmente testemunhas" (Lévy-Bruhl, 2008[1922], p. 194).

Essa breve lista de exemplos evoca incontáveis paralelos para com uma série de temas e questões desenvolvidos pela etnologia sul-americana (bem como, sob vários aspectos, de outras paragens) no último meio século: o uso de partes destacadas do corpo ou pertences de uma pessoa para produção de feitiço, a couvade, o parentesco como consubstancialidade (ou melhor, como processo de consubstancialização), transformações xamânicas ou rituais (ou o ritual e o xamanismo como instâncias de transformação), duplos animais etc. O ponto, vale enfatizar, é importante. Não simplesmente porque tais paralelos apontam para a atualidade da obra de LévyBruhl, mas principalmente porque a participação, na pena do autor, remete a conexões, ou modos de relação, que escapam a um juízo racional cartesiano; o que está em questão é uma conectividade difusa, pois imanente à mentalidade primitiva, que não se coloca do lado da metáfora, mas sim da metonímia. Por diversas que sejam, as relações de participação não são articulações conceituais, portanto abstratas, ou simbólicas entre seres (e coisas), mas conexões reais, dado a realidade que lhes é própria; elas remetem àquilo que, embora não se possa ver 
ou, justamente, conceituar de maneira precisa, passa entre ou conecta os seres e as coisas, processo esse que, como vimos, é seu próprio meio de constituição. E é aí, segundo percebo, que reside o sentido do uso que Lévy-Bruhl faz do termo "místico": sendo ele próprio vago, o que o termo captura não é algo positivo, mas sim negativo, modos de relação que escapam à divisão racional e empirista do mundo entre material e imaterial, entre natural e sobrenatural.

Talvez se pudesse dizer que, por importante que possa ser essa ordem de relações que a participação encerra, isso não é tudo - para lembrar uma das expressões prediletas de Lévi-Strauss, crítico sempre irônico de Lévy-Bruhl; que, ainda sim, há lugar para a metáfora. Penso, porém, que o ponto central da participação, o que Lévy-Bruhl tentava capturar, ou o que capturou na tentativa de fazer algo ligeiramente diferente, eram certas propriedades do pano de fundo relacional imanente às sociocosmologias indígenas. Entretanto, é bem verdade que o que uma tal leitura faz, se o leitor ou a leitora me concedem o ponto, é muito mais ajudar a recuperar a obra de Lévy-Bruhl para a história da antropologia do que propriamente trazer alguma novidade em termos teórico-etnográficos. Afinal, suas percepções sobre, para voltar apenas a um exemplo, corpo e pessoa, ainda que muito instigantes para a produção etnológica atual, foram incomparavelmente melhor desenvolvidas por esta do que por nosso autor - vide a percepção da centralidade do corpo para as sociocosmologias ameríndias (Seeger; Damatta; Viveiros de Castro, 1979) e seus desenvolvimentos no que diz respeito ao parentesco como um processo de consubstancialização - ver, entre outros, Coelho de Souza (2001; 2004), Vilaça (2002), Rival (1998), Gow (1997a) - e a correlata elaboração do próprio conceito de corpo (Viveiros de Castro, 2002; Lima, 2002). Mas há um aspecto, talvez, em que possamos extrair uma ideia da obra de Lévy-Bruhl que, se não completamente inovadora, se situa em um terreno no qual alguns desenvolvimentos ainda estão por vir: o conceito de "território" implicado em seus escritos.

Se, como vimos, "tudo implica uma participação", entre seres, entre seres e objetos, no que tange ao território, não poderia ser diferente. Se o indivíduo participa de seu grupo, há também participação "[...] 
entre o grupo e seu totem, entre o grupo e seus ancestrais míticos, [entre o grupo e] o solo, do qual ele vive e sobre o qual ele vive" (Lévy-Bruhl, 2002[1949], p. 57, grifos meus). Isso implica, é claro, um entendimento da relação para com a "natureza" não como organizada segundo as leis de causalidade natural, mas segundo uma orientação "mística".

A natureza que cerca um determinado grupo, uma tribo ou uma família de tribos, por exemplo, aparece assim em suas representações coletivas, não como um objeto ou como um sistema de objetos e fenômenos regidos por leis fixas, de acordo com as regras do pensamento lógico - mas como um conjunto movente de ações e reações místicas, cujos objetos, seres, fenômenos, são apenas veículos e manifestações, conjunto que depende do grupo, como o grupo depende dele. Orientada diferentemente que a nossa, preocupada acima de tudo com as relações e propriedades místicas, tendo por lei principal a lei da participação, a mentalidade dos primitivos interpreta necessariamente de forma diferente da nossa aquilo que nós chamamos de natureza e experiência. Ela vê sobretudo a comunicação de propriedades, por transferência, por contato, por transmissão à distância, por contaminação, por corrupção [souillure], por possessão, por uma multiplicidade de operações que, em uma palavra, fazem participar, imediatamente ou depois de um tempo mais ou menos longo, um objeto ou um ser a uma dada virtude. (Lévy-Bruhl, 1910, p. 103-104, grifos meus)

Ainda que, em certos momentos, Lévy-Bruhl descreva essa participação com tendo lugar entre um indivíduo e um território, ele parece dar muito mais importância à sua dimensão coletiva: os indivíduos participam do território de seu grupo, na medida em que o 'fundamento místico' dessa participação, por assim dizer, são as "representações coletivas" do grupo. E, se há grupos diversos, cada um (misticamente) ligado à terra que é sua, um território implica um conjunto de participações assim como de exclusões místicas: ele participa dos seres que o habitam e exclui aqueles que não o habitam, pois participam de outro. Em uma palavra, o grupo é sua terra, assim como a terra é o grupo que a habita. Que a leitora ou o leitor me permitam uma última citação, mais extensa. 
Nesse mundo fechado, que tem assim seu espaço, sua causalidade, seu tempo, um pouco diferentes dos nossos, as sociedades se sentem solidárias com outros seres ou conjuntos de seres, visíveis e invisíveis, que habitam com elas. Cada grupo social, conforme seja errante ou sedentário, ocupa um território mais ou menos extenso, cujos limites são, em geral, claramente fixados por ele e pelos seus vizinhos. Ele não é apenas seu senhor, com direito exclusivo, por exemplo, de nele caçar ou de nele colher frutos. O solo lhe "pertence", no sentido místico do termo: uma relação mística liga seus vivos e seus mortos às potências ocultas de todas as espécies que povoam essa terra, que lhe permitem nela viver e que, sem dúvida, não toleram a presença de nenhum outro. Da mesma forma que, em virtude de uma participação íntima, aquilo que esteve em contato imediato e constante com um homem - suas vestes ou ornamentos, suas armas, seu rebanho-é esse próprio homem, e é por isso que, quando ele morre, frequentemente eles não podem pertencer a ninguém mais, e o acompanham em sua nova condição; do mesmo modo, a porção de terra em que vive um grupo humano é esse próprio grupo: ele não poderia viver em outros lugares, e qualquer outro grupo, caso quisesse a ele se assemelhar e nele viver se exporia ao piores perigos. Desse modo, vemos, entre tribos vizinhas, conflitos e guerras a propósito de incursões, de raides [sic], de violações de território, mas não de conquistas propriamente ditas. Eles destruirão um grupo, e não anexarão a terra dele. De que serviria, se nele se encontraria a hostilidade temível dos 'espíritos' de todo o tipo e de espécies animais e vegetais, que nele predominam e que, sem dúvida, fariam a vingança dos vencidos? Não se poderia viver aí, e seria inevitável aí morrer. (Lévy-Bruhl, 2008[1922], p. 452).

Um território, em suma, é "um amontoado de participações e de exclusões místicas" (Lévy-Bruhl, 2008[1922], p. 453).

$$
\text { * * * }
$$

Como se pode notar, Lévy-Bruhl não usa o termo "território" como um conceito estável. Antes, ele o utiliza de maneira mais ou menos frouxa, valendo-se de outros termos como "região do espaço", "solo", "país" (contrée) ou "terra" de maneira intercambiável. Minha 
preferência por "território" se dá em função da confluência entre a abordagem do autor e o termo karajá hãwa, que é frequentemente traduzido pelos indígenas por, justamente, "território". Voltaremos a isso logo a seguir. Aqui, cabe assinalar que, a despeito da variação terminológica, os argumentos de Lévy-Bruhl guardam semelhança com uma literatura mais recente sobre lugar e/ou paisagem.

As conexões entre pessoas, coisas, animais, espíritos e um território não são meramente representadas, i.e., não são "construções sociais" ou "culturais", uma adição de uma camada de significação sobre um substrato que é o espaço; antes essas conexões são reais, os seres que habitam um lugar estão nele implicados - ver, por exemplo, Hirsch (1997), Ingold (2000), Gow (1997b). A relação entre o grupo e o território, note-se, é recíproca: cada 'região do espaço'

[...] participa dos animais reais ou místicos que nela vivem, das plantas que nela crescem, das tribos que a habitam, dos ventos e das tempestades que nela sobrevêm etc. (Lévy-Bruhl, 2008[1922], p. 205)

Pessoas e lugares, em suma, se constituem reciprocamente - ver, por exemplo, Casey (1996). O território de Lévy-Bruhl, assim, não é um espaço cartesiano, sobre o qual relações (místicas, se quisermos) tem lugar; é, para retomar os termos do autor, um "conjunto movente de ações e reações místicas", ou melhor, é um dos termos dessas relações de participação.

Em outro lugar (Nunes, 2013), inspirado também pela obra de Lévy-Bruhl, analisei os trânsitos dos Karajá de Buridina a dois territórios habitados por seres Outros (a cidade, que é "a aldeia dos brancos", e uma determinada porção da mata próxima à aldeia, que é "território das onças"), argumentando que, pessoas e lugares se constituindo reciprocamente, os lugares estabilizam a perspectiva dos seres seus habitantes, de modo que estar em um lugar implica estabelecer uma relação com a perspectiva dos seres para os quais aquele lugar é uma aldeia ou um território - ver também Coelho de Souza (2009). Aquele texto, a seu modo, era já uma demonstração de como um grupo determinado (humano ou não) e o território no qual vive participam um do outro. Aqui, porém, não me deterei sobre a 
constituição dos lugares (i.e., o estabelecimento de participações), mas sobre as relações entre lugares heterogêneos, ou entre as participações e exclusões que, em um "mesmo" território, se "amontoam" - para lembrar a frase com a qual encerramos o tópico anterior. Tratando do caso karajá, o que quero explorar mais detidamente é a natureza desses "amontoados".

Pois um hãwa (um "território" associado a uma aldeia), em sua conotação mais ampla, abarca territórios ocupados por seres Outros; e, ainda mais, territórios heterogêneos, o de humanos e espíritos, por exemplo, se superpõe intensivamente. Lévy-Bruhl não leva ele próprio suas análises até esse ponto, permanecendo com seu foco voltado para a percepção global desses "conjuntos de ações e reações místicas". Desdobrando sua análise, porém, pode-se reconhecer diferenciações internas a esses conjuntos, de modo que, se um grupo e seus ancestrais, por exemplo, participam de um mesmo território, ele não é exatamente o mesmo para cada um deles; "compartilhado" por seres distintos, um "mesmo" território é ontologicamente heterogêneo. E aqui o termo "amontoado de participações" é extremamente sugestivo. Pois se há participações e exclusões, há também coexistências (Soares-Pinto, 2017), superposição intensiva de territórios heterogêneos em um mesmo lugar que é, a um só tempo - para lembrar uma das expressões prediletas de Lévy-Bruhl -, um território humano e um território de espíritos, por exemplo; um território, em suma, que difere de si mesmo. Para explorar a questão, levando Lévy-Bruhl ao país dos Karajá, quero me deter sobre a conformação territorial da aldeia de Santa Isabel do Morro (Ilha do Bananal). Antes, porém, é preciso que entendamos o que é, para esses indígenas, uma aldeia e um território.

\section{Ixỹ hãwa: coletivo de parentes territorialmente localizado}

Os Karajá, grupo falante de uma língua Macro-Jê (Davis, 1968³), são habitantes imemoriais da calha do rio Araguaia, que corta o Brasil Central, margeando os estados de Goiás, Mato Grosso, Tocantins e Pará. Suas aldeias se estendem por um vasto território, deste o alto curso do rio, na confluência com o rio Vermelho, até o baixo Araguaia, onde faz a divisa entre os estados de Tocantins e Pará. A maioria 
de suas aldeias, porém, se concentra na região de Ilha do Bananal (Médio-Araguaia, TO), a maior ilha fluvial do mundo, com cerca de dois milhões de hectares.

Em tempos recentes, todas suas aldeias se situam nos barrancos altos do rio, os poucos pontos imunes à alagamento no período das cheias. Até o começo do século XX, porém, os Inỹ - como se autodenominam os Karajá $a^{4}$ moravam nas praias, como gostam de lembrar. Havia, com efeito, um regime sazonal de ocupação do espaço. Algumas aldeias, em locais mais altos, eram pontos de refúgio durante as grandes enchentes do Araguaia - período chamado pelos Inỹ de bèòra. Quando a água ia cedendo lugar aos grandes bancos de areia do tempo da seca (wyra), a população da aldeia ia mudando-se para as praias. Em alguns casos, uma aldeia de enchente e uma praia são referidas como pertencendo a um mesmo grupo local, que ocupava cada um em uma época do ano. Em outros, uma aldeia em local alto abrigava, quando da cheia do rio, grupos territoriais distintos. E há relatos de que, quando mais o rio secava, as famílias iam se dividindo e mudando de sítio. O movimento das pessoas acompanhava o das águas - ver Krause (1941, p. 255) e Toral (1992, p. 103).

A cada aldeia, hãwa, é associado um território, que circunscreve basicamente os locais por onde sua população circula, com fins diversos: áreas não alagáveis onde geralmente se faz as roças, os trechos do rio e lagos onde pescam, as áreas de mata onde coletam materiais ou caçam. Os limites desse território são definidos com precisão e respeitados pelas outras aldeias 5 . Há, por exemplo, um furo chamado wayry tòla na parte sul da Ilha do Bananal, no curso do Araguaia, que é um ponto de pesca coletiva de tartaruga - o alimento inỹ por excelência - utilizado por várias aldeias. Mas como o lugar "é do pessoal de Fontoura", são os homens dessa aldeia que tem a prerrogativa de fazer a primeira despesca anual lá; apenas depois disso, está "liberado", como os Karajá dizem, para as demais aldeias. Hãwa, com efeito, designa tanto uma aldeia quanto o território a ela associado - ver também Rodrigues, (2008, p. 247, nota 7). Uma outra tradução oferecida pelos Karajá para hãwa, além de "aldeia" e "território", é, de modo mais genérico, "lugar". Hãwa, portanto, é uma aldeia/território/lugar; é um território associado a uma 
aldeia, ou uma aldeia associada a um território - talvez a polissemia do termo resida, justamente, na implicação recíproca entre uma aldeia e seu território. E, importante notar, assim como os Karajá tem suas aldeias/territórios (inỹ hãwa), outras gentes também o têm. As cidades, por exemplo, são tori hãwa, as "aldeias" ou "territórios" dos brancos; os diversos $i x y \tilde{j} u$, os outros índios, têm seus hãwa; e assim, também, os muitos seres que habitam o cosmos, havendo aldeias/territórios de animais (como as onças - ver Nunes (2013) ou de espíritos como os woràsỹ (o coletivo anônimo dos mortos - ver infra).

Se hãwa enfatiza um aspecto territorial, há termos para se referir à "aldeia" que remetem ao coletivo (de parentes) que a habita. Uma maneira comum de se referir a uma aldeia é utilizando o termo mahãdu, que é geralmente traduzido pelos Karajá por "o pessoal": hãwalò mahãdu, "o pessoal da aldeia Santa Isabel", bàtõiry mahãdu, "o pessoal de Fontoura". De maneira análoga, pode-se referir a uma aldeia por meio do termo sỹ, "parentes". Quando uma pessoa diz wasỹ-kí, literalmente "nos meus parentes", ela está se referindo à sua aldeia, ou à sua casa, dependendo do contexto. Como quem diz "lá no meu pessoal", "lá entre os meus". Toral oferece para o termo as traduções de "meu lugar" e "minha família". "Meu lugar' remete ao local onde vive atualmente, à uma comunidade concreta. 'Minha família' é o termo que descreve a parentela à qual se liga e que existe nesse local. Wasy [sic] parece marcar de maneira enfática a existência de grupos de descendência ou parentelas associados a locais determinados" (Toral, 1992, p. 72 , grifos meus $)^{7}$. Esse lastro territorial das parentelas foi enfatizado por Patrícia Rodrigues (2008, p. 548), em sua etnografia sobre os Javaé. A autora argumenta que, para este grupo, a descendência não pode ser separada da residência, respondendo a uma espacialização da sociedade.

Os ancestrais de alguém são referidos como os seus lahina, palavra que contém um componente espacial, ao invés de genealógico, expresso através do sufixo $n a^{8}$. Literalmente falando, lahina significa 'o lugar (na) da avó (lahi $)^{\prime}$, indicando que os ancestrais não são um grupo de quem se descende pela via matrilinear, mas um grupo de pessoas que se define pela co-residência em um determinado espaço, associado principalmente à figura das avós ancestrais. (Rodrigues, 2008, p. 556, grifo meu) 
Mas é principalmente, segundo entendo, o conceito de ixỹ que evidencia que um coletivo (de parentes) é, necessariamente, um grupo territorial. Ixỹ designa o espaço residencial da aldeia (em contraposição ao pátio ritual), assim como um coletivo mulheres ${ }^{9}$. Nesse último sentido, é complementar a ijoi, que se refere a um grupo de homens, operando como um pronome de primeira ou terceira pessoa do plural. Quando algumas mulheres vêm chegando, pode-se dizer ixỹ rarèri, "a mulherada está vindo"; ou um grupo de mulheres pode dizer, com o mesmo significado, karòirènỹkre (-òi-, raiz plural do verbo "ir/vir") ou ixỹ rakre, "nós vamos". Mas ixỹ também se refere à comunidade aldeã: da mesma maneira que se pode dizer inỹ hãwa, diz-se ixỹ hãwa. De modo mais restrito, ixỹ designaria o espaço residencial, as fileiras de casas à beira do rio, em oposição ao pátio ritual masculino, itxoina + , ijoina $\widehat{o}$ (lit., "o que serve para a rapaziada", ou "o lugar da rapaziada"). Ao se referir, portanto, à aldeia como ixỹ, ixỹ hãwa, faz-se uma equação entre a aldeia e o espaço residencial, excluindo - e não subsumindo - o pátio masculino. O pátio ritual, os Inỹ dizem explicitamente, está fora da aldeia ${ }^{10}$.

Se $i x y ̃$ pode designar a aldeia, o termo, então, faz referência a um coletivo de pessoas, de parentes. Quando se diz, por exemplo, $i x \tilde{y}$ hãwa, está se referindo a um "lugar/território" de um ixỹ, i.e., de um grupo inỹ. Aqui, há duas coisas a se notar. Primeiro, a proximidade do campo semântico de inỹ ("nós", "gente") e ixỹ. Para Nathalie Pétesch (1992, p. 87, ênfase minha), um dos usos desse último termo é para designar "[...] toda formação organizada de seres viventes - e, portanto, todos os grupos com características humanas - ligados a um território". Nessa acepção, prossegue ela, ixỹ se oporia a inỹ, que remete "a identidade coletiva, entidade relativamente homogênea, comunidade mais cultural que territorial, mais cósmica que terrestre. Os Inỹ, somos nós; os Ixỹ, estes são os outros" (Pétesch, 1992, p. 87). Ora, mas os Inỹ referem a si próprios, em vários contextos, como um ixỹ; assim como, hoje, em ocasiões em que se identificam a todos os outros índios em contraposição aos brancos, podem se dizer ixỹju, "estrangeiros", do ponto de vista dos brancos. Antes que oposição, portanto, há uma certa sobreposição entre os dois termos. Mas enquanto inỹ se refere à humanidade enquanto 
condição, ixỹ se refere a um "pessoal" ou a um "povo", um coletivo concreto de pessoas (humanas umas para as outras) - ver Nunes (2016, p. 237-242).

Segundo e, de certo modo, como consequência do exposto acima, há uma associação, de um lado, entre humanidade e um princípio feminino e, de outro, entre alteridade e um princípio masculino ${ }^{11}$. $\mathrm{O} i x y ̃$, o espaço residencial da aldeia, é por excelência o lugar da produção de parentesco, i.e., da produção de pessoas humanas. Os homens se transformam em uma gama variada de espíritos no curso dos rituais coletivos de praça, mas também, é certo, tem um aspecto feminino, igualando-se às mulheres - ou melhor, sendo a elas subsumidos enquanto parentes, membros de um ixỹ. Ixỹ, assim como mahãdu, designa uma coletividade. Não uma qualquer - como mahãdu, que pode designar um coletivo de pessoas como de objetos -, mas uma coletividade de pessoas associadas a um lugar, a um território específico e que, por isso, são presumivelmente humanas para si mesmas: ou seja, uma coletividade de parentes. Há, portanto, uma implicação recíproca entre hãwa e ixỹ: um coletivo de parentes só pode existir territorialmente, i.e., em um hãwa, ao passo que um território só pode existir, em oposição a outros, por ser habitado por um coletivo de parentes, i.e., um ixỹ. Entre os dois, para voltar a Lévy-Bruhl, há participação.

O território inỹ, nesse sentido, é um conjunto de "participações e exclusões". Cada lugar é o território de um grupo, seja ele um outro grupo karajá (o "pessoal" de outra aldeia), Javaé, de outra etnia (os vizinhos Xavante e Tapirapé, por exemplo), ou de determinados animais etc. Essa repartição do mundo em uma multiplicidade de hãwa, porém, não é de todo extensiva, os limites desses territórios não coincidindo perfeitamente uns com os outros. Esse é, com efeito, o caso dos territórios das aldeias inỹ: há, como disse, limites precisos onde um começa e outro termina. Mas não é o caso dos territórios Outros: seja o dos brancos, o de outros índios, o de animais ou o de espíritos, o hãwa de uma aldeia karajá é entrecortado por outros territórios. O caso da constituição da aldeia de Santa Isabel nos servirá de exemplo. 


\section{Território de Santa Isabel}

A história de Santa Isabel, a maior e mais conhecida aldeia karajá atual, remonta a um tempo próximo do começo do mundo. Uma narrativa ${ }^{12}$ conta como os Inỹ que moravam no Berahatxi - o Fundo do Rio, patamar inferior do cosmos - saíram do Araguaia para habitar o Mundo de Fora - Ahãna, o patamar intermediário do cosmos, onde os Inỹ atuais vivem. Wokubèdu ỹ, Woubèdu ỹ foi quem descobriu a passagem e conduziu seu pessoal para o lado de fora. Isso ocorreu em um local chamado inỹsèdyna, próximo à foz do rio Tapirapé, onde, ainda hoje, está a aldeia Itxala. Mas, junto com Woubèdu, o mito revela em dado momento, também saíram os ixỹju, os outros índios. Eles todos viveram juntos e pacificamente por um tempo. Até que, como era inevitável, dado o comportamento inapropriado e agressivo dos $i x y ̃ j u$, teve lugar um conflito iniciado pelos índios Kumỹkò. A harmonia, então, cedeu lugar a um estado de guerra generalizado.

Um desses grupos $i x \tilde{j} j u$, os Wèrè, extremamente belicosos, subiram o rio e se estabeleceram na região mediana da Ilha do Bananal. Periodicamente, entretanto, eles desciam promovendo reides contra os Inỹ e outros grupos. Em uma dessas investidas, os Wèrè mataram o pai de Teribrè, que ainda era apenas um menino. Outra história ${ }^{13}$ conta como Teribrè e seu irmão mais novo (Wanahua, um Kayapó adotado), se prepararam durante muitos anos para vingar seu pai. Eles passavam o dia inteiro dentro d'água, até que sua carne ficou tão dura que as flechas não mais penetravam. Por fim, já crescidos e plenamente preparados, os dois, sozinhos, investem contra os Wèrè e dizimam praticamente todos os homens, restando só o chefe, as mulheres, velhos e crianças. Os Wèrè se rendem e vão morar junto a Teribrè, na região próxima de onde todos saíram do fundo do rio. Depois de anos, Teribrè os manda embora. Os Wèrè, então, entregam para ele seu rio, o Araguaia, e sua comida, alguns tipos de peixe, e sobem até sua antiga aldeia. De lá, atravessam a Ilha do Bananal, se estabelecendo no rio Javaés. Estes, dizem, são os ancestrais dos Javaé atuais. Com a expulsão dos Wèrè, os Inỹ estabelecem domínio sobre o vale do Araguaia.

Várias famílias subiram o rio e, muito tempo depois dessa guerra, havia grupos karajá morando nas proximidades da antiga aldeia dos 
Wèrè, localizada em um barranco alto à beira do rio. Abandonada, uma densa manta tomou conta do lugar e, ali, foram as onças que encontraram abrigo, constituindo, assim, um hãwa para si. Os Inỹ, em contrapartida, habitavam praias e outros barrancos, acima e abaixo dali $^{14}$. E assim estavam quando, em 1927, um encarregado do Serviço de Proteção aos Índios (SPI), M. Bandeira de Melo, chegou à região para fundar o Posto Indígena voltado para a população Karajá. O primeiro grupo com o qual estabeleceu contato foi de Birihoa, que habitava a grande praia em frente à antiga aldeia Wèrè. Bandeira de Melo sugere aos Karajá que o posto fosse fundado em um morro na margem esquerda do rio - limite norte da atual cidade de São Félix do Araguaia (MT) -, mas Birihoa nega, temendo ataques dos Xavante. Esse belicoso grupo Jê costumava empreender expedições de guerra na época da seca, descendo o Rio das Mortes e chegando até o Araguaia, de modo que conflitos eram frequentes. Birihoa, então, sugere o barranco alto na margem oposta, precisamente o sítio da antiga aldeia Wèrè. O SPI inicia o trabalho de abertura da mata e funda o Posto. Com o tempo, outros grupos territoriais se juntam ao de Birihoa. Pelos relatos dos Inỹ, pude localizar 14 aldeias cujos grupos territoriais se juntaram em torno do Posto, três delas no Rio das Mortes (Tèsè, Hãlòkòè Làku + Hãlòè Luu $\widehat{\jmath}$ e Mànawitxi, cuja importância veremos mais adiante), cuja foz dista aproximadamente $20 \mathrm{~km}$ à montante do local onde o SPI se instalara (Nunes, 2016, p. 72-76). A vida do Posto foi curta-depois de alguns anos de intensa atividade, em 1931 ele entra uma rápida e avassaladora decadência, que culminaria com seu abandono em menos de um ano -, mas os Karajá continuaram reunidos ali, dando origem à aldeia de Santa Isabel do Morro, ou Hãwalò.

Quando esses grupos territoriais se juntaram ao posto, iniciaram o processo de constituição daquele lugar como uma inỹ hãwa, uma aldeia/território propriamente humano, inỹ: construindo suas casas em linhas paralelas ao rio, um pátio ritual com uma hetokrè +, hetoàrè ऽ ("casa de aruanã" ou "casa dos homens"), fazendo roças etc., bem como passando a produzir-se enquanto parentes sobre aquele chão e com aquele chão. O que vale dizer, iniciaram o processo de constituição de um $i x \tilde{y}$, um coletivo de parentes territorialmente localizado. No entanto, 
muitos dos locais utilizados naquela região (para pesca, plantio, coleta de materiais, sepultamento etc.) já eram, certamente, associados a algum (ou alguns ${ }^{15}$ ) dos grupos territoriais que se uniram em torno do Posto, e continuaram a sê-lo depois da conformação da aldeia nova. Um cemitério novo foi feito abaixo da aldeia, por exemplo, mas os antigos continuaram a ser utilizados e, até recentemente, algumas pessoas ainda foram sepultadas nos cemitérios de seus grupos territoriais de origem (o último caso, do importante líder Watau, data do início dos anos 2000). O território de Santa Isabel, assim, foi construído como um novo hãwa se utilizando, em parte, de uma bricolagem com (os elementos d)os hãwa das aldeias antigas. Os Karajá mantêm essa memória bastante viva. Em expedições de pesca, coleta, ou simples andanças pelo rio, comumente me contavam que tal ou qual lugar era uma aldeia, relembrando quem era o chefe daquele grupo territorial e quais moradores da Santa Isabel atual são seus descendentes.

Mais ainda, eles também se lembram das histórias dos tempos antigos, da empreitada heroica de Teribrè, e dizem que "essa aldeia, na verdade, é dos Wèrè. Nós chegamos aqui depois". O principal cemitério da aldeia - há outro, de criação recente - é, com efeito, o cemitério da antiga aldeia Wèrè, no qual os Karajá passaram a enterrar seus mortos. Um cemitério sobreposto ao outro, supõe-se, os mortos dos dois grupos também se sobrepõem (cf. infra). Também alguns locais dentro do território de Santa Isabel guardam em seus nomes a memória de seus "donos" originários: em frente à aldeia, há um furo chamado Wèrè tòla, "furo dos Wèrè"; em um local não muito distante continente a dentro, há uma mata fechada chamada Wèrè bàjiku + , Wèrè bàjiu ô. "mata dos Wèrè". O hãwa de Santa Isabel, portanto, é uma composição heteróclita de diversos hãwa, que, embora "incorporados" - no sentido de produzidos como próprios -, guardam as marcas de suas origens.

Formulado dessa maneira, o problema parece se colocar em termos da história do território de Santa Isabel, composto de lugares que, outrora, participavam de outros territórios. Como se a heteroclicidade fosse apenas de sua constituição histórica, e não de sua existência atual. Mas esse, certamente, não é o caso. De fato, nem os Wèrè nem as linhas de fissão entre os grupos territoriais que formaram Santa 
Isabel parecem ser um problema hoje. Em um caso, porque os Wèrè como tais não mais existem, tendo se tornado, por assim dizer, um outro povo, com seu território próprio; em outro, porque as associações de locais determinados aos grupos territoriais a partir dos quais a aldeia se formou não resultam, a princípio, em nenhuma espécie de prerrogativa de uso ${ }^{16}$ para seus descendente atuais, podendo, ao contrário, ser irrestritamente explorados por todos os coaldeãos (mas não por pessoas de outras aldeias). De direito, entretanto, a composição heteróclita desse território permanece atual. Uma família que descenda de um grupo territorial determinado "tem direito", como dizem, à antiga aldeia daquele grupo, podendo reivindicar aquele local (hãwa) para moradia - e, por conseguinte, o território (hãwa) que o conforma.

Mas é sobretudo no que se refere aos territórios dos Outros que essa questão se mostra de maneira mais clara. Passemos, então, a esses casos.

\section{Os Lugares dos Outros}

Comecemos pelos mortos. Pessoas que morrem de morte "normal", i.e., por várias formas de adoecimento que provocam um agravamento progressivo até o falecimento, se tornam, depois de um processo conduzido pelos mortos eles próprios, wakuràs $\tilde{y}+$, woràs $\tilde{y}{ }^{\lambda 17}$. Esse termo pode ser referir ao "espírito" de uma pessoa falecida em específico, mas, em geral, remete à coletividade anônima dos mortos. Eles vivem sob o cemitério. Nas palavras de Sòkròwè, os woràsỹ "têm uma aldeia. O cemitério é a terra deles, fica no fundo do cemitério". Segundo Donahue (1982, p. 162-165), essa aldeia é "igual à aldeia karajá, com casas"; ver também Lima Filho (1994, p. 153).

Ainda que tenham sua aldeia, na qual, dizem os Karajá, eles vivem, os woràs ỹ estão sempre acompanhando os vivos em suas atividades cotidianas: quando um homem vai para pescaria, quando uma mulher vai buscar lenha, ou simplesmente 'fazendo companhia' para os vivos, em suas casas. Por isso os Inỹ fazem o xiwè $e^{18}$ sobre a comida cotidiana. Fazendo assim, eles garantem o auxílio e a proteção de seus mortos. Se um homem está na pescaria, por exemplo, seus woràsỹ afastam 
as piranhas, arraias ou outros bichos que possam lhe fazer mal. Eles também dão sinais, geralmente sob a forma da aparição de algum animal em um local não usual para a espécie, de que alguma coisa está errada: de que a pescaria não renderá frutos ou que um parente irá morrer, por exemplo. Se não se faz xiwè, os woràs y ficam bravos e deixam seus "parentes" vivos à sua própria sorte - sobre isso, ver Nunes (2012, p. 107-108), Lima Filho (1994, p. 56), Toral (1992, p. 213), Pétesch (1992, p. 90, nota 3).

Além disso, os woràs ỹ tem um papel fundamental no Hetohokỹ, o grande ritual coletivo de iniciação masculina. Em vários momentos da festa, a coletividade masculina da aldeia (ijoi) se transforma em woràsỹ para realizar tarefas específicas: embora o que quem olhe de fora veja é um grupo de homens, são os woràsỹ que cortam o grande mastro (tòo $)$ que será erguido no centro da praça, trazem-no do mato para a aldeia e o fincam no chão, são eles que erguem as estruturas de madeira e palha em torno das quais se desenrola o ritual, são eles que fazem as caçadas coletivas, são eles que cantam e dançam na praça e são eles, por fim, que protagonizam a disputa ritual com os woràs ỹ da aldeia visitante em torno do tòò. Não somente no ápice do ritual, porém, grupos de woràsỹ se rivalizam. Em alguns momentos, os homens da aldeia anfitriã e da visitante se visitam reciprocamente, ocasiões nas quais seus woràsỹ disputam lutando o ijèsu, a luta corporal inỹ. E não apenas nessas ocasiões. Em Santa Isabel, os woràsỹ de quatro aldeias antigas - três de rio acima, as já citadas do Rio das Mortes, e uma de rio abaixo, chamada Huòtàby - se agregam progressivamente aos dali. No momento em que eles chegam, também lutam ijèsu com os woràs ỹ locais, para depois se juntar a eles (para uma descrição mais detalhada do ritual, ver Nunes (2016), Souza Filho (1987a; 1987b; 1987c; 1987d).

Se os woràs ỹ têm sua aldeia (hãwa), eles, presumivelmente, também têm um território (hãwa). Entretanto, esse território, tal como podemos imaginá-lo, não se distingue extensivamente do território da aldeia Santa Isabel. Antes, ele lhe superpõe. A aldeia dos mortos é seu local de moradia, mas eles exploram, junto com os vivos, os mesmos lugares que esses (lagos, trechos do rio, praias, matas). Além disso, o território dos woràs ỹ, assim como o de Santa Isabel, de certo modo, não é um espaço 
único e homogêneo, com limites bem marcados, mas uma composição de várias aldeias-cemitérios, espalhadas à beira do Araguaia e do Rio das Mortes. Se, em certo sentido, os hãwa dos woràsỹ estão "dentro" do hãwa de Santa Isabel, pois eles são os mortos dos habitantes daquela aldeia, eles também estão "fora", pois são aldeias-territórios de Outros; pois os woràs ỹ não são humanos, estando bem mais próximos dos aõni do que destes.

Os anõni 우, aõni $\widehat{o}$ são uma gama variada de seres que povoam o universo inỹ. O contato com eles é inerentemente perigoso, precisando, sempre que inevitável ou desejado, ser mediado xamanicamente. Com alguns deles, como os mascarados ijasò, é possível estabelecer relações produtivas, se tomados os necessários cuidados que sua presença na aldeia no curso de um ciclo ritual próprio demanda. Já outros, são monstros antropofágicos (inỹròdu, "comedores de gente") para com os quais o contato deve ser evitado a todo custo. Assim como os woràsỹ, esses seres têm seus hãwa. Se os Inỹ são moradores da beira do rio, os aõni são, em geral, bàdèrahyky làdu + , bàdèrahy làdu $\widehat{O}$, "moradores do mato", um espaço em grande medida inculto e antissocial. Bàdèrahy é uma designação geral, que comporta uma variedade de lugares, muitos dos quais, é claro, os Karajá exploram, seja para caça, pesca ou coleta de materiais variados. Há diversos relatos de encontros de homens pois são principalmente esses que transitam no mato para fins diversos - com algum aõni em uma ocasião em que o primeiro passava pelo território do segundo, quer por que motivo seja. Encontros com poucas consequências - como avistar um aõni ao longe, ou mesmo apenas ouvi-lo -, e alguns com consequências importantes ou severas - como o ataque de um aõni, que pode levar a um adoecimento iniciatório à carreira de xamã ou mesmo a adoecimentos graves, até fatais.

Vejamos brevemente, para citar apenas um exemplo, o caso do Aõnihikỹ, "o grande ãoni", ou Ilabièhèkỹ, "o grande avô". Esse é, certamente, o ser mais perigoso de todo o universo inỹ. Ele é trazido para a aldeia no final dos sete dias de reclusão dos meninos no Hetohokỹ, e mesmo o xamã que sai com a entidade, vestindo sua máscara, precisa ser acompanhado por um ajudante que lhe ministra remédio. Todo o trajeto que o Ilabièhèkỹ percorre é coberto por palhas, de modo a 
impedir completamente que ele seja visto pelo público. Ainda assim, quando ele sai, todas as pessoas ficam de costas, pois olhá-lo de frente seria letal. O aõni, apenas ao olhar no olho de alguém, come seu fígado, provocando a morte depois de pouquíssimo tempo, durante o qual a pessoa vomita sangue. Há relatos de homens que o avistaram no mato, situação na qual o único que se pode fazer é jogar-se ao chão, com a face voltada para baixo, esquivando-se, assim, do olhar letal. Mas há também relatos de encontros fatais.

Um ser tão perigoso, poder-se-ia imaginar, só poderia coexistir com os Inỹ se seu território fosse afastado mato adentro, de modo que as possibilidades de encontro se reduzissem a um mínimo. Isso, em geral, é o que se passa, mas não necessariamente; pois se assim o é de fato, não o é de direito. Há um desses aõni que, embora habite o mato, tem uma "estrada" que liga seu território ao Araguaia. De quando em vez, ele sai do rio na alta madrugada e ruma por essa estrada para seu hãwa. Ocorre que tal estrada encontra com o rio exatamente onde está a aldeia de Santa Isabel, de modo que, quando ele sobe da água, caminha por entre as casas, em um trilheiro que todos sabem qual é, antes de se embrenhar no mato. Há pelo menos dois relatos de homens o viram ali. Um deles voltava da casa de aruanã no meio da madrugada e percebeu a entidade de longe, ao que se virou e saiu correndo no sentido contrário. O outro, porém, se sentiu mal pouco tempo depois de ver o Ilabièhèkỹ, começou a vomitar sangue e morreu rapidamente. Nesse caso, dois territórios em tudo antitéticos se superpõem.

Sobre os aõni, cabe notar que, embora sejam ditos comumente "moradores do mato", há também os bèralàdu mahãdu, "moradores do rio". Entre eles estão os aruanãs mascarados que, em sua maioria, habitam o Berahatxi, mundo subaquático, patamar inferior do cosmos. Andando em vários trechos do rio e nos lagos (assim como no mato), os Inỹ estão sempre alerta aos habitantes desses lugares e os perigos que podem representar. Em vários momentos, ouvi-los dizer que "aqui tem aõni". Alguns homens mesmo evitam ir a certos lugares por conta disso. Mas, é claro, não é possível evitar todos. Um trecho do rio ou um lago habitado por um aõni, portanto, é um lugar denso, por assim dizer, pois é um hãwa para mais de um ser/grupo, e, por isso mesmo, 
ele não é uno, mas sim, difratado por diferentes perspectivas - sensu Viveiros de Castro (2002), Lima (1996; 1998), dois hãwa. O que há é uma superposição.

Um último caso que vale mencionar é o dos Tori, os não-indígenas; mais especificamente os da pequenina cidade de São Félix do Araguaia (MT), distante apenas cerca de cinco quilômetros de Santa Isabel, na margem oposta do rio. Os Karajá circulam por ali cotidianamente, seja para fazer compras no comércio local, para frequentar o colégio estadual (como é o caso de cada vez mais jovens), para trabalhar (vários deles são empregados do Distrito Sanitário Especial Indígena - DSEI Araguaia), para competir em campeonatos esportivos, para participar de festas na cidade ou simplesmente para passear. Com efeito, quem anda pelas ruas do centro de São Félix vê índios em todo lugar. E os Karajá gostam bastante dessa proximidade.

A cidade, como disse, é tori hãwa, a "aldeia" ou "território dos brancos". Entretanto, São Félix está em um espaço densamente ocupado pelos Karajá até a chegada do SPI em 1927 - o primeiro habitante da cidade, considerado seu fundador, só chegou ali em 1941. "Aqui, antigamente, era aldeia", dizem os índios. No alto do morro que é o limite norte da cidade há um cemitério utilizado até recentemente (ver supra); ali havia uma aldeia chamada Hãwalòlàby; a pouquíssimos quilômetros do limite sul da cidade, há outro cemitério, que pertencia a uma aldeia chamada Latèni Ixèna; na praia imediatamente em frente a cidade, havia outra aldeia, Kòtirara ${ }_{+}$, Òtirara $\hat{\delta}$, cujo ponto de agremiação no inverno era um outro morro, ao sul do centro de São Félix, no qual há hoje um bairro; além disso, há um brejo entre as partes velha e nova da cidade no qual há um grande buritizal, e lá era, como ainda é, um dos bons locais onde os karajá extraem de olho de buriti; e, por fim, a mata na encosta norte do morro de Hãwalòlàby, onde hoje há uma fazenda, é o local onde os homens - ou melhor, os woràsy - de Santa Isabel cortam o mastro ritual tòo pelo menos desde a chegada do SPI. Em vista de tudo isso, os Karajá dizem que o lugar onde está a cidade "é nosso" - e disso não há dúvidas. "Se a gente quiser tomar a cidade, a gente toma, porque aqui é de Santa Isabel", me disse um amigo diversas vezes, sempre esclarecendo, na sequência, 
que poderiam tomar, mas não irão, pois não querem. Com efeito, na única ocasião em que os Karajá começaram a se mobilizar para solicitar ao órgão indigenista a demarcação de uma terra na margem matogrossense (onde está a cidade de São Félix), sua intenção não era demandar uma área grande, que abarcasse toda a cidade, mas apenas um perímetro diminuto - a mata de onde tiram o mastro ritual tò ${ }^{19}$. E enfatizaram, justamente, que não queriam "tomar São Félix". Para eles, como dito, a proximidade com a "aldeia dos brancos" é em geral apreciada, ainda que apresente seus problemas.

Uma vez mais, superposição. A cidade é o território (hãwa) dos brancos, guardando as marcas de sua socialidade. Mas, de outro ponto de vista, ela é parte do hãwa de Santa Isabel, evidenciando as marcas de um lugar feito humano pelos ancestrais dos Inỹ atuais. O território da aldeia engloba a cidade e, a um só tempo, a cidade o limita, pois é um território Outro. E essa mesma questão pode ser estendida a todo o vale do Araguaia. Não apenas porque ocorre o mesmo com outras aldeias e cidades vizinhas - como São Domingos e a cidade de LuciaraMT ou Buridina e a cidade de Aruanã-GO; mas porque, sendo os Inỹ habitantes imemoriais do vale do Araguaia e, mais ainda, tendo sua humanidade emergido do fundo dessas águas, entendem que toda a extensão da calha do rio é seu território. "Esse Araguaia, aqui, é nosso", por isso têm direito de andar por onde bem entenderem ao longo do rio, pescando, extraindo materiais de suas margens etc. E São Félix não é a única cidade à margem do Araguaia, dentro desse imenso hãwa que é o rio para a humanidade inỹ.

\section{0 "Amontoado" e a Vida}

Superposição ou, para retomar Lévy-Bruhl, amontoado: o território karajá é "um amontoado de participações e exclusões". Um hãwa é ele mesmo diferindo de si próprio. Mais, ou antes que um mosaico, no sentido de um único território cuja composição é uma bricolagem com (partes de) outros territórios, um hãwa "amontoa" parcialmente uma série de outros, diferentes entre si. Os lugares, assim, possuem uma densidade ontológica própria, sendo, 'a um só tempo', hãwa diferentes para diferentes seres. Um amontoado não é o produto de 
uma soma, nem de uma partilha, nem de uma estratificação, nem de qualquer tipo de operação extensiva; um amontado de participações é um estado, ou um evento, intensivo. O território karajá, em suma, é uma superposição intensiva de territórios heterogêneos.

Se os grupos são seus territórios, assim como os territórios são os grupos seus habitantes, parafraseando Lévy-Bruhl, a coexistência, ou superposição, de múltiplos hãwa implica "[...] uma congregação mais ou menos temporária, mais ou menos 'harmônica', de uma pluralidade de agentes" (Coelho de Souza et al., 2016, p. 49). Um amontoado, assim, implica relações entre essa pluralidade de seres, a produção continuada de um território podendo ser descrita como uma delicada política cosmoterritorial. Os Karajá extraem madeira (para construção de casas, por exemplo) de matas que são, ao menos algumas delas, territórios de aõni. Para que isso seja possível, é claro, não se pode ignorar que se está em um hãwa Outro. É preciso, antes, que se esteja atento à medida em que as participações heteróclitas de humanos e espíritos para com um "mesmo" lugar se amontoam ou se excluem. Há certas condições, em suma, para que um hãwa qualquer possa durar no tempo - i.e., continuar a ser produzido enquanto tal. Condições essas que, poderia tentar resumir, dizem respeito a uma vívida percepção de suas superposições e dos modos de relação que elas implicam, bem como de uma avaliação cuidadosa do que se pode ou não fazer, levando em conta as consequências, ou os efeitos, dessas ações - uma cosmopolítica do respeito. Pois um território como um "amontoado de participações e exclusões", ou um hãwa, não é uma "[...] categoria geopolítica dependente de ato de tomada ou de relação de domínio sobre uma certa extensão de terra" (Coelho de Souza et al., 2016, p. 25), mas um espaço de vida denso, no qual diferentes existências territorializadas (i.e., participações) se sobrepõem.

Encerremos esse percurso com o trecho de uma fala do xamã karajá Cléber Axiwèra, durante o $1^{\circ}$ Encontro de Pajés Karajá (São Félix do Araguaia, agosto de 2015). Nela, Axiwèra usa os termos inỹ, ixỹju e aõni de maneira intercambiável. Segundo entendo, o que ele está afirmando é que os múltiplos seres que habitam os diversos hãwa que conformam um território, ainda que alguns deles se apresentem 
como a antítese da humanidade inỹ (certos aõni, por exemplo, como o Ilabièhèkỹ de que falávamos a pouco), todos eles são gente (inỹ, $i x \tilde{y} j u)^{20}$ - para si próprios, escusado dizer -, seres dotados de agência, personitude e, é claro, território.

No rio, também tem gente como nós, mas nós não conhecemos. No rio tem gente, os peixes, os botos, os piroscas [pirarucus] são os Inỹ, são povo inỹ. Está aí! O rio está sendo poluído, as matas estão sendo derrubadas, os bichos estão sendo tirados [...] Fala que é bicho, mas não é bicho, não! É igual a nós, inỹ, povo inỹ, ixỹju. Está lá! Os fazendeiros derrubam as matas, acabam com as moradias do povo que está morando ali dentro. Porque na cidade acontece furacão? Porque que acontece? Na cidade não tem as matas, está tudo derrubado. Então esse povo, o povo aõni, inỹ, está lá se juntando para poder atacar a casa do povo Tori. Estão derrubando [a casa deles] porque eles também estão zangados. Aquele lá é o lugar deles! Se eles veem as pessoas [tori], eles brigam, igual nós brigamos no ministério. Porque nós estamos brigando lá no ministério? Porque nós estamos aqui, vendo os Tori. Eles [os aõni] não, quem pode ver somos nós, são os pajés, os Tori não estão vendo.

Os Karajá "brigam no ministério", poderíamos complementar, justamente porque os Tori, com sua destrutiva - para si e para outros, para pessoas e lugares - política de homogeneização e de rígida compartimentalização territorial, não logram enxergar o que para os Inỹ é tão evidente: que habitar um hãwa, viver na e da terra que é sua, e que se o é, esse delicado exercício cosmopoliticoterritorial, é participar desse "amontoado"; que, como disse Lévy-Bruhl, ser é participar.

\section{Notas}

1 “Naturalmente que a lógica à qual se refere L-B é a habitual no século XIX, essencialmente normativa - e não como ela seria vista posteriormente, como uma ciência das estruturas formais do pensamento indígena." (Cardoso de Oliveira, 1991, p. 97, nota 4).

2 Todas as traduções dos originais em francês aqui citados foram feitas por mim.

3 A língua karajá, o inỹrybè, apresenta uma diferenciação da fala pelo sexo do falante - ver Ribeiro (2012). As variantes feminina e masculina das palavras aparecem indicadas no texto por meio dos símbolos $q$ e $\widehat{\delta}$, respectivamente. 
4 Há, com efeito, três grupos que se autodenominam Inỹ: os Karajá (cujas aldeias se estendem desde o alto Araguaia até um pouco abaixo da Ilha do Bananal), os Javaé (habitantes do braço direito da Ilha, o rio Javaés) e os Ixỹbiòwa (habitantes do trecho encachoeirado do rio, já próximo ao local onde ele desagua no Tocantins). Apesar do inegável ar de família, os três grupos se consideram, em geral, como distintos.

5 Sobre os Javaé, Rodrigues (2008, p. 654) diz que, “[...] os habitantes de cada aldeia reconhecem com precisão os limites de seu território de uso, evitando adentrar nos rios e lagos utilizados pelos moradores de aldeias vizinhas".

6 Wa-, possessivo de primeira pessoa; $s \tilde{y}$, "parentes"; - $k i$, locativo.

7 Essa associação de parentelas a locais determinados se relaciona também à clivagem interna aos Inỹ entre ibòkò mahãdu q, ibòò mahãdu $\widehat{o}$, "pessoal de rio acima", e iraru mahãdu, "pessoal de rio abaixo". Essa divisão opera tanto entre os Karajá como um todo quanto dentro de cada aldeia. Assim, o "pessoal de baixo" que mora em Santa Isabel (uma aldeia de ibòo, "de cima"), por exemplo, são geralmente descentes de grupos territoriais de rio abaixo que, em algum momento, migraram de seus lugares de origem. Essas pessoas podem usar o termo wasỹ para designar tanto sua aldeia atual quanto o território/aldeia de origem de sua família. Importante notar, porém, que os Karajá nutrem um ideal de endogamia de aldeia, de modo que, por mais que toda aldeia tenha uma minoria de pessoas oriundas de outros lugares (tendo migrado por motivos diversos, incluindo, eventualmente, o casamento), cada sítio tende a conformar um grupo de parentesco e territorial específico.

8 A posposição -na é, para ser mais preciso, primeiramente um instrumental, formando

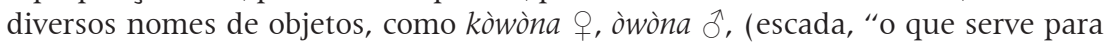
subir"), hèrana (panela, "o que serve para cozinhar"), rubuna (feitiço, "o que serve para a morte, para matar"), krèsyna + , àrèsyna ổ (tesoura, "o que serve para cortar"). De maneira derivada, ele também é usado, em uma quantidade bem menor de casos, como um locativo, como no caso em questão ou em ijoina (praça dos homens, "o que serve para os homens", i.e., "o lugar dos homens").

9 Ou, ainda, os porcos queixada. Para o que nos interessa aqui, não cabe discutir em detalhes o campo semântico comum às mulheres e porcos do mato, que se articula ainda ao termo ixỹju - lit. "dente (juu) de queixada (ixỹ)" -, "estrangeiros", "nãoInỹ". Sobre isso, ver Nunes (2016, p. 235-242).

${ }^{10}$ Isso também é evidenciado linguisticamente. Quem está em casa sai (verbo de raiz -òhòny-) para o ijoina. Os homens, em casa, dizem muitas vezes apenas aròhònỹkre, "eu vou sair", e sabe-se que eles estão indo para o pátio ritual. Quem está no pátio, por sua vez, entra (verbo de raiz -lò-) para o ixỹ. No ijoina, escuta-se frequentemente os homens, quando estão indo embora, dizerem simplesmente aralokre, "eu vou entrar", e sabe-se que eles estão indo para casa. Quando se está fora da aldeia, na pescaria, por exemplo, também se "entra" de volta para o ixỹ.

11 Patrícia Rodrigues (2007;2008), em sua etnografia Javaé, insiste na tese oposta, de que há uma associação clara entre alteridade e um princípio feminino. Essa associação traçada pela autora se ancora sobretudo em três elementos: a mitologia, as músicas de ijasò (espíritos vestidos com máscaras de palha que são trazidos para a aldeia para dançar e cantar em um ciclo ritual) e a relação que os ijasò e os aõniuma categoria de espíritos - estabelecem em certos rituais javaé. Em minha tese de doutorado, me demorei sobre cada um desses aspectos, apontando como o argumento da autora não se sustenta para o caso karajá e que, ainda mais, dependente que é 
de certos pressupostos teóricos, o próprio material javaé poderia ser lido de outra maneira - ver Nunes (2016, p. 242-254).

12 Nunes (2016, p. 553-556, M12) "A saída do fundo do rio".

${ }^{13}$ Nunes (2016, p. 571-578, M19) "A guerra de Teribré contra os Wèrè".

14 Os Karajá, com efeito, foram se espalhando rio acima - as aldeias do baixo curso nunca deixaram de existir - chegando até ao alto Araguaia, onde hoje está a aldeia Buridina. Na virada do século XIX para o XX, porém, esses grupos mais meridionais que se estabeleceram ao sul da Ilha do Bananal, foram progressivamente retornando a seus territórios de origem, restando, acima da Ilha, apenas a aldeia Buridina (GO) e um pequeno núcleo karajá na cidade de Cocalinho (MT). Sobre esse movimento de expansão rico acima, ver Toral (1992).

15 Ao que tudo indica, a conformação dos "territórios" dessas aldeias antigas parece mais complexa do que o descrito acima, em termos de seus limites precisos. Alguns desses diferentes grupos moravam em aldeias (de verão) próximas, entretinham relações de parentesco consideravelmente estreitas e se reuniam em uma mesma aldeia de inverno - verão e inverno, aqui, se referem respectivamente às estações seca e chuvosa. De modo que, muito provavelmente, locais de pesca, de coleta e de sepultamento (mas não de plantio, provavelmente) eram, em alguma medida, partilhados por mais de uma aldeia. Essa é uma questão que cabe investigar mais a fundo.

${ }^{16}$ Excetuando-se, talvez, os cemitérios, ainda que, nesse caso, não se trate propriamente de prerrogativa, mas de preferência.

17 Mortes repentinas, nas quais pessoas que estão bem falecem em virtude de um acontecimento pontual (acidente, assassinato, certos tipos de feitiço como o de enforcamento, etc.), resultam na transformação em hurè, um tipo de espectro bastante ameaçador e perigoso para os vivos. Esses também têm sua aldeia, que, por uma questão de economia textual, não cabe explorar aqui (para uma descrição mais detalhada, ver Nunes (2016, p. 338-339).

18 Espécie de "reza" feita sobre a comida e direcionada, no mais das vezes, aos woràsỹ, oferecendo-se a comida para que eles partilhem. O xiwè é uma injunção curta, que, no cotidiano se limita, na maior parte do tempo, a um simples hỹỹy!, com as mãos abertas sobre a comida. A fórmula não é de todo padronizada, mas é geralmente algo como: Kiè-mỹ ini hè! [sem tradução] Ijõ biràsỹbènỹ! ("Comam um pouco!"), podendo ser acrescida de pedidos específicos como wadèè aruki-mỹ! ("me protejam"), ou aõbinabinahakỹ waràbi irèhè-mỹ biijàranỹ! ("Afastem de mim as coisas ruins/ perigosas").

19 Em mais de um momento, na verdade, os Karajá conversaram entre si sobre isso, sempre motivados por conflitos com o proprietário da fazenda onde se localiza tal mata. Em nenhuma dessas vezes uma demanda formal foi apresentada ao órgão indigenista, a iniciativa esfriando em passo paralelo ao apaziguamento do conflito.

20 Os ixỹju ("outros índios", "estrangeiros") são Outros, não-inỹ, por definição. Ainda assim, os Karajá, como dito acima, por vezes se referem a si próprios como ixỹju - a fala que se segue também o ilustrará. Em outro lugar (Nunes, 2016, p. 329 242) fiz uma análise do campo semântico desses termos, argumentando que essa possibilidade de comutação surge da percepção de que um grupo ixỹju é também um $i x \tilde{y}$, um coletivo de parentes territorialmente localizado, sendo, portanto, humanos para si mesmos. 


\section{Referências}

CARDOSO DE OLIVEIRA, Roberto. Razão e afetividade: o pensamento de Lucien Lévy-Bruhl. Campinas: Editora da Unicamp, 1991.

CASEY, Edward. How to get from space to place in a fairly short stretch of time: phenomenological prolegomena. In: FELD, Steven; BASSO, Keith. (org.). Senses of place. Washington, University of Washington Press, 1996. p. 13-52.

COELHO DE SOUZA, Marcela S. Nós, os Vivos: "construção da pessoa" e "construção do parentesco" entre alguns grupos jê. Revista Brasileira de Ciências Sociais, [S.l.], v. 16, n. 46. p. 69-96, 2001.

COELHO DE SOUZA, Marcela S. Parentes de Sangue: Incesto, substância e relação no pensamento Timbira. Mana, Rio de Janeiro, v. 10, n. 1, p. 25-60, 2004.

COELHO DE SOUZA, Marcela S. Três nomes para um sítio só: a vida dos lugares entre os Kĩsêdjê (Suyá), comunicação. In: IV CONGRESSO DA ASSOCIAÇÃO PORTUGUESA DE ANTROPOLOGIA - Painel Convidado VII: Classificar: objectos, sujeitos, acções. Lisboa, 9-1 1 de setembro 2009.

COELHO DE SOUZA, Marcela S. et al. 2016. T/terras indígenas e territórios conceituais: incursões etnográficas e controvérsias públicas. Projeto de pesquisa. Entretterras, [S.l.], v. 1, n. 1, 2016.

DAVIS, Irvine. Some Macro-Jê relationships. International Journal of American Linguistics, [S.l.], v. 1, n. 34, p. 42-47, 1968.

DONAHUE, George. A contribution to the ethnography of the Karaja Indians of Central Brazil. 1982. Tese (Doutorado) - Universidade da Virgínia, 1982.

GOLDMAN, Marcio. Razão e diferença: afetividade, racionalidade e relativismo no pensamento de Lucien Lévy-Bruhl. Rio de Janeiro: Editora de UFRJ/GRYPHO, 1994.

GOLDMAN, Marcio. Lévi-Strauss e os sentidos da história. Revista de Antropologia, [S.l.], v. 1-2, n. 42, p. 223-238, 1999.

GOW, Peter. O parentesco como consciência humana: o caso dos Piro. Mana, Rio de Janeiro, v. 3, n. 2, p. 39-65, 1997a.

GOW, Peter. Land, people, and paper in Western Amazonia. In: HIRSCH, Eric; O'HANLON, Michael. (org.). The anthropology of landscape: perspectives on place and space. Oxford: Clarendon Press, 1997b. p. 43-62. 
HIRSCH, Eric. 1997. Introduction. Landscape: between place and space. In: HIRSCH, Eric; O'HANLON, Michael. (org.). The anthropology of landscape: perspectives on place and space. Oxford: Clarendon Press, 1997. p. 1-30.

INGOLD, Tim. The temporality of the landscape. In: INGOLD, Tim. The Perception of the Environment: Essays in livelihood, dwelling and skill. London: Routledge, 2000. p. 189-208.

KRAUSE, Fritz. Nos Sertões do Brasil. Revista do Arquivo Municipal de São Paulo, [S.l.], v. 77, p. 179-194, 1941.

LÉVY-BRUHL, Lucien. Les fonctions mentales dans les sociétés inférieures. Paris: Presses Universitaires de France, 1910.

LÉVY-BRUHL, Lucien. A letter to E. E. Evans-Pritchard. The British Journal of Sociology, [S.l.], v. 3, n. 2, p. 117-123, 1952[1934].

LÉVY-BRUHL, Lucien. L'âme primitive. Coleção “Les classiques des sciences sociales", Université du Québec, Chicoutimi. Edição eletrônica, 2002[1927]. Disponível em: http://classiques.uqac.ca/classiques/levy_bruhl/ ame_primitive/ame_primitive.pdf. Acesso em: 19 ago. 2019.

LÉVY-BRUHL, Lucien. Lucien Lévy-Bruhl (1938-1939). Carnets. Coleção "Les classiques des sciences sociales", Université du Québec, Chicoutimi. Edição eletrônica, 2002[1949]. Disponível em: http:// classiques.uqac.ca/classiques/levy_bruhl/carnets/Carnets.pdf. Acesso em: 19 ago. 2019.

LÉVY-BRUHL, Lucien. A mentalidade primitiva. São Paulo: Paulus, 2008 [1922].

LIMA FILHO, Manuel Ferreira. Hetohokỹ: um rito Karajá. Goiânia: Editora UCG, 1994.

LIMA, Tânia Stolze. O dois e seu múltiplo: reflexões sobre o perspectivismo em uma cosmologia Tupi. Mana, Rio de Janeiro, v. 2, n. 2, p. 21-47, 1996.

LIMA, Tânia Stolze. Para uma teoria etnográfica da distinção natureza e cultura na cosmologia juruna. Revista Brasileira de Ciências Sociais, [S.l.], v. 14, n. 40, p. 43-52, 1999.

LIMA, Tânia Stolze. O que é um corpo? Religião e Sociedade, [S.l.], v. 22, p. 9-19, 2002.

NUNES, Eduardo S. O território das onças e a aldeia dos brancos: lugar e perspectiva entre os Karajá de Buridina (Brasil Central). Journal de la Société des Américanistes, [S.l.], v. 99, n. 2, p. 135-164, 2013. 
NUNES, Eduardo S. 2016. Transformações karajá. Os “antigos" e o "pessoal de hoje" no mundo dos brancos. 2016. Tese (Doutorado) Universidade de Brasília, Brasília, DF, 2016.

PÉTESCH, Nathalie. La pirogue de sable. Modes de Représentations e d'Organization d'une Société du Fleuve: Les Karajá de l'Araguaia (Brésil Central). 1992. Tese (Doutorado) - Université de Paris x (Natèrre), Paris, 1992.

RIBEIRO, Eduardo Rivail. A grammar of Karajá. 2012. Tese (Doutorado) - Departamento de Linguística, Universidade de Chicago, 2012.

RIVAL, Laura. Androgynous parents and guest child: the Huaorani couvade. The Journal of the Royal Anthropological Institute, [S.l.], v. 4, n. 4, p. 619-642, 1998.

RODRIGUES, Patrícia M. O meio como o lugar da história. Campos, [S.l.], v. 8, n. 1, p. 33-43, 2007.

RODRIGUES, Patrícia M. A caminhada de Tanỹxiwè: uma teoria Javaé da história. Tese (Doutorado) - Departamento de Antropologia da Universidade de Chicago, Chicago, Illinois, 2008.

SEEGER, Anthony; DAMATTA, Roberto; VIVEIROS DE CASTRO, Eduardo B. A construção da pessoa nas sociedades indígenas brasileiras. Boletim do Museu Nacional, N.S., Antropologia, 32, p. 2-19, 1979.

SOARES-PINTO, Nicole. De coexistências. Sobre a constituição de lugares djeoromitxi. R@U, [S.l.], v. 1, n. 9, p.61-82, 2017.

SOUSA FILHO, Odilon João de. A festa da casa grande dos karajá (1).

Publicações do Museu Histórico de Paulínia, [S.l.], n. 32, p. 21-30, 1987a.

SOUSA FILHO, Odilon João de. A festa da casa grande dos karajá (2).

Publicações do Museu Histórico de Paulínia, [S.l.], n. 33, p. 48-57, 1987b.

SOUSA FILHO, Odilon João de. A festa da casa grande dos karajá (3). Publicações do Museu Histórico de Paulínia, [S.l.], n. 34, p. 76-83, 1987c.

SOUSA FILHO, Odilon João de. A festa da casa grande dos karajá (4).

Publicações do Museu Histórico de Paulínia, [S.l.], n. 35, p. 100-107, 1987d.

TORAL, André. Cosmologia e Sociedade Karajá. 1992. Dissertação (Mestrado) - PPGAS-Museu Nacional, UFRJ, 1992. 
VILAÇA, Aparecida. Making kin out of others in Amazonia. The Journal of the Royal Anthropological Institute, [S.l.], v. 8, n. 2, p. 347-365, 2002.

VIVEIROS DE CASTRO, Eduardo B. Perspectivismo e multinaturalismo na America indígena. In: VIVEIROS DE CASTRO, Eduardo B A inconstância da alma selvagem. São Paulo: Cosac \& Naify, 2002. p. 345-399.

Recebido em: 14/1 1/2017

Aceito em: 14/12/2017

\section{Eduardo S. Nunes}

Doutor pela Universidade de Brasília (UnB)

E-mail: eduardo.s.nunes@hotmail.com 